\title{
Investigating the mediating role of visitor satisfaction in the relationship between memorable tourism experiences and behavioral intentions in heritage tourism context
}

S. Mostafa Rasoolimanesh, Siamak Seyfi, Raouf Ahmad Rather and Colin Michael Hall

\begin{abstract}
Purpose - This paper aims to investigate the interplay of memorable tourism experiences (MTE) dimensions in driving behavioral intentions of heritage tourists through the mediating role of satisfaction.

Design/methodology/approach - Empirical data were collected from tourists in the heritage city of Kashan, Iran. Partial least squares-structural equation modeling (PLS-SEM) and fuzzy-set qualitative comparative analysis (fSQCA) were applied to analyze the data.

Findings - The results of PLS-SEM showed that three dimensions of MTE as follows: local culture, involvement and knowledge, significantly directly or indirectly influence tourists' behavioral intention toward a destination. However, the results of $f_{S} Q C A$ identified greater heterogeneity among the respondents by highlighting the positive effects of hedonism and novelty on satisfaction and revisit and word-of-mouth intentions.

Originality/value - This study enriches the empirical evidence on MTE by constructing a composite picture of the memorability of tourists' experiences within a heritage tourism context. This study is one of the first to investigate the effects of dimensions of MTE on behavioral intentions using both symmetric (PLS-SEM) and asymmetric approaches to identify the more significant dimensions of MTE, as well as sufficient combinations of dimensions to predict behavioral intentions.
\end{abstract}

Keywords Tourist experience, Heritage tourism, WOM intention, Revisit intention,

Memorable tourism experiences (MTE)

Paper type Research paper

基于遗产旅游情境下的游客满意度 对难忘旅游体验和行为意向之间关系的中介效应的研究

研究目的: 本文旨在研究难忘旅游体验 (MTE) 各维度通过满意度这个中介变量来驱动遗产旅游游客行为 意图的机制

䂰究设计/方法论/研究方法 : 实证数据是从伊朗遗产城市卡尚的游客那里收集的。本㸴究采用偏最小二乘 结构方程模型 (PLS-SEM) 和模糊集定性比较分析 ( fSQCA) 对数据进行分析

㸴究发现：偏最小二乘结构方程模型的研究结果表明, 难忘旅游体验 (MTE) 的三个维度：当地文化、 参与度和熟悉程度, 显著地直接或间接地影响游客对目的地的行为意向。然而, 模糊集定性比较分析的 研究结果表明受访者间存在更大的异质性, 其结果凸显了享乐主义和新鲜感对满意度、重游意向和口碑 (WOM)意向的正效应

独创性/价值：本研究通过构建遗产旅游背景下游客体验难忘性的相互影响机制, 丰富了关于难忘旅游体

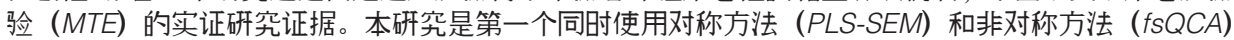
来探究MTE各维度对行为意向的影响的研究之一, 通过这种方式可以识别出MTE各维度中更为重要的维 度以及维度组合, 以此来预测行为意向

关键词: 难忘旅游体验口游客体验口碑意向口重游意向口遗产旅游
(Information about the authors can be found at the end of this article.)

Received 15 February 2021

Revised 15 May 2021

17 June 2021

Accepted 2 July 2021

(c) S. Mostafa Rasoolimanesh, Siamak Seyfi, Raouf Ahmad

Rather and Colin Michael Hall. Published by Emerald

Publishing Limited. This article is published under the Creative Commons Attribution (CC BY 4.0) licence. Anyone may reproduce, distribute, translate and create derivative works of this article (for both commercial and non-commercial purposes), subject to full attribution to the original publication and authors. The full terms of this licence may be seen at http://creativecommons.org/ licences/by/4.0/legalcode 
Estudio del papel mediador de la satisfacción del visitante en la relación entre las experiencias turísticas memorables y las intenciones de comportamiento en el contexto del turismo patrimonial

Propósito : Este artículo investiga la influencia de las dimensiones de las experiencias turísticas memorables (ETM) en el fomento de las intenciones de comportamiento de los turistas del patrimonio a través del papel mediador de la satisfacción.

Diseño/metodología/enfoque : Se recogieron datos empiricos de turistas en la ciudad patrimonial de Kashan, Irán. Para analizar los datos se aplicaron las técnicas partial least squares - structural equation modeling (PLS-SEM) y fuzzy-set qualitative comparative analysis (fSQCA).

Conclusiones : Los resultados que proporcionó el análisis PLS-SEM mostraron que tres dimensiones de las ETM: cultura local, implicación y conocimiento, influyen significativamente, de forma directa o indirecta, en la intención de comportamiento de los turistas hacia un destino. Sin embargo, los resultados del enfoque fSQCA identificaron una mayor heterogeneidad entre los encuestados al destacar los efectos positivos del hedonismo y la novedad sobre la satisfacción y las intenciones tanto de volver a visitar el destino como de realizar una comunicación de boca a boca (WOM).

Originalidad/valor : Este estudio enriquece la evidencia empirica sobre las ETM al construir una imagen combinada del carácter memorable de las experiencias de los turistas dentro de un contexto de turismo patrimonial. Este estudio es uno de los primeros en investigar los efectos de las dimensiones las ETM en las intenciones de comportamiento utilizando enfoques simétricos (PLS-SEM) y asimétricos para identificar las dimensiones más significativas las ETM, así como para determinar las combinaciones necesarias de dimensiones para predecir las intenciones de comportamiento.

Palabras clave : Experiencias turísticas memorables (ETM); Experiencia turística; Boca a boca; Intención de revisita; Turismo patrimonial

\section{Introduction}

Memorable experiences that "create lasting memories that a visitor will reminisce about and will share in respective social networks" (Andrades and Dimanche, 2014, p. 108), have been viewed as the ultimate consumer experience (Sthapit and Bjork, 2019). Previous research suggests that memories of a past trip experience contribute to tourists' subjective well-being (Sthapit et al., 2017), strengthen tourists' place attachment to a place (Sthapit et al., 2017) and is the key personal source of information for destination choice, revisit intention and word-of-mouth (WOM) communications (Oh et al., 2007; Tung and Ritchie, 2011a; Sthapit and Bjork, 2019; Cho et al., 2020). Several studies argue that the memorable tourism experience (MTE) Scale developed by Kim et al. (2012) is strongly context-based and calls for further application of this scale in different contexts (Cho et al., 2020) which reflects one of the aims of this study. While several researchers have emphasized the importance of MTE for the competitive advantage of tourism destinations, there is limited empirical research on MTE in heritage tourism settings and more particularly the impacts of MTE components and dimensions on heritage tourists' behavioral intentions. Hence, these gaps in extant knowledge point to the focus of the present study.

Heritage tourism offers experiences that involve visiting or engaging with "places, artifacts and activities that authentically represent the stories and people of the past and present" (Hargrove, 2002, p. 10). Heritage tourism, as with many other recreational and tourism practices, has emerged as a significant element of tourists' memorability (Lee, 2015; Rasoolimanesh et al., 2021), making it a form of experiential consumption (Hall and Zeppel, 1990; Garrod and Fyall, 2000, 2001; Richards, 2018). Heritage tourism is regarded as one of the largest and most significant segments of contemporary tourism as evidenced by increased recognition of the growing economic and social value of tangible and intangible cultural heritage to the tourism sector (e.g. UNESCO World Heritage and intangible cultural heritage lists) (Abraham and Poria, 2020; Timothy and Nyaupane, 2009). The experiential consumption of cultural heritage tourism has been identified as major element of the memorability of tourist experiences (Van Dijk and Weiler, 2009; Mgxekwa et al., 2017). Several authors have emphasized the importance of the memorability of heritage tourism 
experiences (Lee, 2015; Seyfi et al., 2020) and the increasing quest for memorable cultural experiences as part of the recent growth in demand for cultural tourism (Richards, 2018). Significantly, Mgxekwa et al. (2017) show that providing tourists with memorable experiences at the places visited is one of the most significant parts of generating revenue for cultural heritage sites. Therefore, an improved understanding of the tourist experience and behavioral intentions at heritage sites and destinations is integral to better meeting the expectations of this market (Richards, 2018; Seyfi et al., 2020).

The present study considers the mediating effect of tourist satisfaction on the relationship between MTE components and tourists' behavioral intentions. The literature has well documented that satisfaction functions as a trigger for destination choice, helping tourists form their overall experience of a destination and consequently affecting revisit and WOM intentions (Oh et al., 2007; Tung and Ritchie, 2011a; Hollebeek and Rather, 2019). As such, further investigation is crucial to determine any differences in the impact of tourist satisfaction on tourists' behavioral intention across MTE components.

To fill the gaps in the existing research stated above, the purpose of the current study was threefold. First, to investigate the components of MTE impacting heritage tourists' behavioral intention (i.e. revisit intention, WOM intention). Although several factors have been recognized as influencing the relationship between MTE and revisit intention (e.g. perceived image; Kim, 2018; Zhang et al., 2018), a lack of tourism-based conformity is observed, thereby warranting further investigation. Second, to extend previous studies and examine the mediating role of satisfaction in effecting the association between MTE and revisit and WOM intention (Chen et al., 2020; Gohary et al., 2020; Zhang et al., 2018). Third, to test Kim et al. (2012) MTE scale in a relatively overlooked heritage tourism context which is seen to a large degree as being a form of experiential consumption (Richards, 2018).

Empirical data were collected from domestic visitors in the heritage city of Kashan, Iran. To analyze the data and assess measurement and structural models, partial least squaresstructural equation modeling (PLS-SEM) has been applied. In addition to PLS-SEM as a symmetric approach, to gain deeper insights, a fuzzy-set qualitative comparative analysis (fsQCA) has been used to identify sufficient and necessary combinations of MTE components on satisfaction, revisit and WOM intentions.

\section{Theoretical background and hypotheses development}

\subsection{Memorable tourism experiences}

Kim et al. (2012) initially conceptualized an MTE framework and define it as a meaningful experience that "is positively remembered and recalled after the event has occurred [that is] selectively constructed from tourism experiences based on the individual's assessment of the experience" ( $p .13)$. They discussed the components of the general tourism experience which facilitates visitor benefits and memories. The MTE components in their suggested scale involve refreshment-, hedonism-, novelty-, local culture-, involvement-, knowledge- and meaningfulness. Each of the components is discussed below in Section 2.1.1. This seminal scale of MTE has been confirmed in other studies. For instance, in their cross-cultural study using Taiwanese tourists, Kim and Ritchie (2014) validated this scale by testing the predictive-validity of the MTE-scale to examine the impact of MTE on behavioral intentions. Relatedly Kim (2014) developed a 10-dimensional scale, which conceptualizes the destination attributes linked with MTE in southern Taiwan. A similar validation was done by Tsai (2016) in the context of Taiwan's local food experiences to investigate the role of MTE on place attachment, place identity and behavioral intention. The findings also suggest the mediating effects of place attachment and place identity between MTE and behavioral intention. Other scholars have also extended the MTE theoretical model. Chandralal and Valenzuela (2015) added various factors including tour guide performance- and surprise in a study of 35 in-depth interviews and 100-travel blog narratives and consequent 
quantitative analysis of MTE of respondents who had visited destinations in Australia. More recently, Gohary et al. (2020) also examined the MTE on destination satisfaction and tourist's behavioral intentions (see also Zhang et al., 2018).

In addressing the significance of offering tourism experiences which would persist in tourists' memories for a longer period, authors have documented the need and have debated various means to deliver superior MTE (Chen et al., 2020; Cho et al., 2020; Gohary et al., 2020; Kim et al., 2012; Kim, 2018; Zhang et al., 2018; Sthapit et al., 2019). Both quantitative and qualitative studies have been performed to explore MTE and what type of tourist experiences can match MTE, although the findings of such research are mixed. For instance, in their qualitative studies, Tung and Ritchie (2011a) acknowledged four vital components of MTE (expectations, recollection, affect and consequentiality) while Tung and Ritchie (2011b) identified five key MTE components (family milestones, identity formation, freedom pursuits, nostalgia reenactment and relationship development). In addition, few quantitative studies have investigated the impact of tourist experience on memory (Oh et al., 2007; Kim et al., 2010; Sthapit et al., 2019). The findings of their studies suggest that the experience components of esthetic, educational, escapist, entertainment, local culture, hedonism and involvement impact tourists' memories positively and become memorable experiences. Recently, Rather (2020) examined the impact of tourist experiences dimensions (i.e. feel, sense, act, think and relate) on behavioral intention. To date, this means that although recognized as important, there exists no general agreement with what constitutes or represents MTE.

This research uses Kim et al. (2012) scale as a foundation to explore the direct- and indirect-MTE effects. There are several reasons for this approach. First, the components of different MTE are similar to each other. Second, Kim et al. (2012) scale is the initial and more often cited instrument- in the marketing and tourism literature. Third, various empiricalbased research studies have validated and presented solid support for the scale.

\subsubsection{Memorable tourism experiences components.}

2.1.1.1 Hedonism. In travel experience, Kim et al. (2010) defined hedonism as "pleasurable feelings that excite oneself" (p. 15). While "consuming" tourism products or (experiences), unlike other products and activities, individuals mostly seek enjoyment (i.e. pleasure/ hedonism) (Holbrook and Hirschman, 1982). Coherent with the view that the main objective of consuming tourism products is to pursue pleasurable (or hedonic) experiences; an emotional factor and an important element of tourism experiences (Coudounaris and Sthapit, 2017; Kim, 2014; Kim et al., 2012). In empirical-based tourism works, authors establish that hedonic experiences facilitate tourists to generate memorable experiences. For instance, hedonism acts as the main determinant of the perceived value of the cruise travel experience (Dunman and Mattila, 2005). Tung and Ritchie (2011a, b) contend that positive feelings and emotions linked with tourism experiences, such as excitement and happiness, were crucial factors of MTE. Moreover, Kim (2014) investigated that hedonism is a vital dimension of destination attributes of MTE.

2.1.1.2 Novelty. A psychological feeling of newness is derived from having a new experience (Kim et al., 2012). Novelty has been constantly registered as another key factor of subjectivetourism experience and a prevalent motivation for a person to travel (Dunman and Mattila, 2005; Kim et al., 2012). Many tourists like to select destinations or sites which have different cultures (or lifestyles) to fulfill the desire and need to experience something new (Pearce, 1987). In investigating the MTE antecedents, Chandralal and Valenzuela (2015) corroborated that novelty, that resulted from experiencing something new such as culture-, food- and accommodation- and encountering diverse travel experiences, is a vital factor of MTE.

2.1.1.3 Local culture. Experiencing local culture is widely regarded as a key travel motivation (Coudounaris and Sthapit, 2017) and as a critical factor of tourist experience (Morgan and Xu, 2009). Tung and Ritchie (2011a) confirm that learning local culture, residents' way of life and the destination language significantly enhances MTE. Furthermore, social interaction with local culture helps develop memorable holiday tourist experiences (Morgan and Xu, 2009). 
2.1.1.4 Refreshment. Refreshment is the most distinct attribute of travel or tourism experiences, separating such experiences from those of everyday life (Cohen, 1979; Kim, 2014). For instance, in defining tourism activity, Cohen (1979, p. 181) remarks that refreshment is "essentially [a] temporary reversal of everyday activities - it is a nowork, no-care, no-thrift situation." Furthermore, Turner and Ash (1975) argue that the short-lived distance of visitors from their normal environment enables them to transcend the values (or norms) of everyday life and think from a unique viewpoint. Empirical work supports the significance of refreshment in travel and tourism experiences and its positive influence on visitor's travel memories (Morgan and Xu, 2009; Kim, 2010, 2018).

2.1.1.5 Meaningfulness. Meaningfulness is defined as a sense of great significance, value or increasing one's thinking regarding society and life (Kim, 2014). This factor is linked to the propensity for travelers to look for meaningful experiences for self-development and personal growth (Coudounaris and Sthapit, 2017; Kim, 2014). In the context of MTE, meaningful-tourism experiences are identified as remaining longer in human memory (Tung and Ritchie, 2011a). When individuals learn more regarding the object (destination, site, attraction) and widen their perspectives due to eye-opening travel/ tourism experiences, such experiences can be some of the more memorable experiences of life (Coudounaris and Sthapit, 2017; Tung and Ritchie, 2011a).

2.1.1.6 Involvement. Involvement is a state of interest or motivation about the destination/ object (Kim et al., 2012; Rather et al., 2021). Tourists consider a personally meaningful and relevant experience as more significant than one which is not meaningful and relevant (Rather et al., 2019, 2021). Research findings show that the high levels of involvement in a consumer experience increase its memorability (Coudounaris and Sthapit, 2017). For instance, Pine and Gilmore (1998) suggest that once consumers find themselves immersed in an activity, they are more expected to have a memorable experience. Reflecting this, scholars support the notion that involvement in a consumer experience strengthens individuals' affective feelings while assessing an experience and deeply promotes cognitive analysis (Kim, 2014).

2.1.1.7 Knowledge. Individuals desire to learn new things and build new skills and insights due to their tourism experiences. One of the socio-psychological motivations which predispose tourists to travel is the desire to acquire knowledge (Kim, 2014; Kim et al., 2012), including with respect to destination history, language, geography and/or culture. Indeed, Tung and Ritchie (2011a) confirm that intellectual development was one of the fundamental factors of MTE while Hung and Petrick (2011) also argue that education and learning are a vital components of travel experiences.

\subsection{Memorable tourism experience and satisfaction}

Satisfaction refers to "a positive reaction resulting from the favorable assessment of consumption experience" (Oliver, 1980, p. 47). Tourist satisfaction includes the sum of psychological states which occur from the consumption of tourism experiences (Oliver, 1997; Rather and Hollebeek, 2019). Thus, there is a significant and positive association between tourist experiences and satisfaction (Oh et al., 2007; Ali et al., 2016). For instance, in testing Pine and Gilmore's (1998) MTE four-dimensional model (i.e. education, entertainment, aesthetics and escapism), scholars have documented a significant association between tourism experiences and tourists/cruisers' satisfaction (Oh et al., 2007; Ali et al., 2016).

Oh et al. (2007) explored the effects of MTE's second-order construct on satisfaction and Gohary et al. (2020) investigated the impacts of seven first-order MTE components on satisfaction. Their results show that six-factors out of the seven-MTE components (i.e. hedonism, novelty, refreshment, meaningfulness, involvement and knowledge) influence 
satisfaction. Both studies adopted the MTE-scales and attained parallel results, suggesting that MTE have a significant- and positive- influence on satisfaction. The experiential tourism components contribute towards tourist satisfaction and overlap with the MTE's components. The four-realms of experience also increase satisfaction (Ali et al., 2016; Chen and Chen, 2010). For instance, Chen and Chen (2010) established that three experiential tourism dimensions (i.e. peace of mind, involvement and educational experience) could be used to ascertain tourist satisfaction at Taiwanese heritage sites.

Satisfaction also refers to the psychological state customers experience once confirmation (or disconfirmation) of expectations occurs (Oliver, 1997) and for which customers build an affective-led post consumption judgment (Lim, 2014). Chang et al. (2004) claimed that the more pleasurable and exciting a service consumption experience is, the greater the degree of satisfaction customers feel. Bigné et al. (2005) argued that satisfaction reveals pleasure- and arousal-levels felt. Pleasure and arousal develop from emotions and, in-turn, arousal (i.e. antecedent of emotional-formation) affects pleasure (i.e. hedonism) (Russell, 1980). As hedonism (e.g. emotional and pleasurable components) has been a significant MTEdimension positively effects tourist's satisfaction towards the destination (Zhong et al., 2017). Recently, Lim (2014) also claimed that emotions have a high level of significance in hedonic services and a high level of hedonism positively effects satisfaction in tourism and hospitality services.

In the context of tourism, the novelty has been documented to be specifically important with respect to tourism destinations (Coudounaris and Sthapit, 2017; Lee and Crompton, 1992). Novelty seeking theory offers a sound theoretical foundation in elucidating destination assessment and choice behavior (Assaker et al., 2011; Babu and Bibin, 2004). Novelty is a pivotal factor of travel motivation and affects visitors' decision-making process (Lee and Crompton, 1992). Assaker et al. (2011) argued that novelty has a positive effect on satisfaction with tourists being more satisfied if visitors seek novelty and experience exceeds/meets their expectations. Based on the above arguments, we propose as follows:

H1a. Hedonism has a positive effect on satisfaction.

H1b. Novelty has a positive effect on satisfaction.

Relatedly, the experiential factors of local culture, refreshing experiences, meaningfulness and consumer knowledge are identified as enhancing tourist's capability to recollect past travel experiences and as a critical factor in determining visitor's satisfaction (Ali et al., 2016; Chen and Chen, 2010; Coudounaris and Sthapit, 2017). Similarly, Grissemann et al. (2013) indicated that the level of involvement affects tourist satisfaction with travel service providers. In addition, Ali et al. (2016) suggest that creative tourist experiences (i.e. involvement, peace of mind, learning, escape recognition and interactivity) significantly affect behavioral intentions via satisfaction. The favorable associations between the MTE components and the outcome factors are supported Woodside and Dubelaar's (2002) conceptualization of a tourism consumption system as "the set of related travel thoughts, decisions and behaviors by a discretionary traveler prior to, during and following a trip" (p. 120). The theory asserts that tourist assessment of the destination (site) experience affects their overall destination evaluation and behavior (Woodside and Dubelaar, 2002). Based on these arguments, the following hypotheses are proposed:

H1c. Local culture has a positive effect on satisfaction.

H1d. Refreshment has a positive effect on satisfaction.

H1e. Meaningfulness has a positive effect on satisfaction.

H1f. Involvement has a positive effect on satisfaction.

H1g. Knowledge has a positive effect on satisfaction. 


\subsection{Memorable tourism experience and revisit intention}

Oliver (1997) defines behavioral intention as an individual's "stated likelihood to engage in a behavior" (p. 28). Revisit intention, which is a behavioral intention factor, refers to a customer's intention to re-experience the same tourist destination or product (Gohary et al., 2020; Rather, 2021). MTE is considered as essential for sustainability and destination competitiveness because they potentially impact customer decision-making and future destination choices (Kim and Ritchie, 2014). If tourism destinations can offer MTE to visitors, the possibility of tourist's revisiting that destination would increase (Zhang et al., 2018). In view of that, MTE has been found to significantly impact consumer's behavioral intent to revisit and/or recommend a destination in different contexts (Ali et al., 2016; Kim and Ritchie, 2014; Kim et al., 2010; Tsai, 2016; Zhang et al., 2018). For instance, Tsai's (2016) study shows that MTE has both direct- and indirect- effects on behavior intention mediated through place identity. In investigating the effect of creative tourists' experience on behavior intention in resort hotels Ali et al. (2016) found that tourist experience affects behavior intention indirectly via satisfaction and memory. Kim (2018) identified that the influence of MTE on behavioral intentions both directly, as well as indirectly via tourist satisfaction and destination image among international arrivals visiting Taiwan. Zhang et al. (2018) found that MTE has a direct positive impact on revisit intention towards a city in China.

Tsai (2016) and Zhang et al. (2018) investigated the impacts of MTE's second-order measurement on behavior intention. Kim and Ritchie (2014) examined the effects of seven first-order MTE factors on behavioral intentions. Their results indicate that five-components among seven MTE components (i.e. hedonism, local culture, refreshment, meaningfulness and involvement) impact behavioral intentions to revisit the same destination, repractice the same tourism activities and elevate positive-WOM. These studies adopt the same MTEscales and obtained similar results, signifying that MTE have a significant impact on revisit intention.

Relatedly, the desire to seek hedonic tourism experiences such as enjoyment and excitement (Coudounaris and Sthapit, 2017; Otto and Ritchie, 1996) are critical factors in determining revisit intention and future behavior (Coudounaris and Sthapit, 2017; Kim et al., 2010). Novelty entails the willingness to take psychological-, physical- and social risks for the sake of novel, varied and complex sensations (Coudounaris and Sthapit, 2017). Novelty has been identified as a powerful motivation for leisure tourism behavioral intentions (Dunman and Mattila, 2005; Coudounaris and Sthapit, 2017). Novelty seeking is an inherent quality in some pleasure travel and is expressed as an adventure, thrill seeking, boredom alleviation and surprise (Lee and Crompton, 1992) and is also positively associated with revisit intention as follows:

H2a. Hedonism has a positive effect on revisit intention.

H2b. Novelty has a positive effect on revisit intention.

Many tourism activities can develop tourists' well-being and psychological mood, facilitating learning and self-identity in relation to other cultures, destinations or places (Kim et al., 2012; Chen et al., 2021). Social interaction among tourists and local culture (host community) is recognized as an important factor of tourist experience (Morgan and $\mathrm{Xu}$, 2009). Exploring and understanding local cultures can be critical motivations for some tourists. Those tourists who interact with local culture often build memorable and unique heritage experiences (Kim, 2014; Kim et al., 2012) and is an important aspect in influencing tourists' revisit intention (Coudounaris and Sthapit, 2017; Kim et al., 2010). Further, high value refreshment is a psychological benefit of many tourist experiences as it reduces stress (Kim, 2014). Coudounaris and Sthapit (2017) argued that refreshment is a crucial element in effecting visitors' behavioral intentions. Similarly, meaningfulness facilitates visitors' personal development and change (Kim, 2014). When tourist meaningfulness increases, experience not only becomes more memorable but also is a significant element 
in visitors' revisit intentions (Tsiotsou and Goldsmith, 2012). The following these findings, we posit:

H2c. Local Culture has a positive effect on revisit intention.

H2d. Refreshment has a positive effect on revisit intention.

H2e. Meaningfulness has a positive effect on revisit intention.

Similarly, Clements and Josiam (1995) investigated the relationship between involvementand travel decision making. Their findings revealed that tourists having higher levels of involvement likely travel more repeatedly than to those with less involvement. Rather et al. (2021) also contended that involvement is an important driver of travel decision-making. Knowledge (i.e. education and learning) experiences are central influences in consumer's desire for experience (Pine and Gilmore, 1998). Travel and tourism experiences, including interaction with locals or interpretive tours of a historic destination/site, offer a multitude of distinctive learning opportunities for visitors (Coudounaris and Sthapit, 2017; Kim, 2014). Knowledge (learning) regarding local culture that incorporates the destination's language(s) and residents' way of life considerably increases MTE (Tung and Ritchie, 2011a) and, ultimately revisit intentions. Theories of tourism consumption suggest that tourist evaluation of the destination experience influences their behavior and intentions (Woodside and Dubelaar, 2002). Hence, the subsequent hypotheses are proposed as follows:

H2f. Involvement has a positive effect on revisit intention.

H2g. Knowledge has a positive effect on revisit intention.

H3a. Hedonism has a positive indirect effect on revisit intention through satisfaction.

H3b. Novelty has a positive indirect effect on revisit intention through satisfaction.

H3c. Local Culture has a positive indirect effect on revisit intention through satisfaction.

H3d. Refreshment has a positive indirect effect on revisit intention through satisfaction.

H3e. Meaningfulness has a positive indirect effect on revisit intention through satisfaction.

H3f. Involvement has a positive indirect effect on revisit intention through satisfaction.

H3g. Knowledge has a positive indirect effect on revisit intention through satisfaction.

\subsection{Memorable tourism experience and word-of-mouth intention}

Consumer behavior is mediated by memory which, in turn, influences return decisions (Tung and Ritchie, 2011a). In tourism, empirical studies have reported that MTE significantly affects individuals' future behavioral intentions (e.g. revisit, re-practice and WOM communications) (Rather and Hollebeek, 2021; Kim et al., 2012; Kim and Ritchie, 2014). Adongo et al. (2015) and Tsai (2016) found that MTE significantly influences behavioral intentions to revisit and recommend. Marschall (2012) states that tourists are more probable to revisit a destination where they have had memorable experiences. Prior studies also suggest that MTE significantly affects individuals' behavioral intentions to spread positive WOM (Kim and Ritchie, 2014; Adongo et al., 2015; Tsai, 2016). For example, Zhong et al. (2017) posit that MTE dimensions (hedonism, novelty, local culture, refreshing, meaningfulness, involvement and knowledge) effects WOM communication. Similarly, Adongo et al. (2015) reported that memorable local food experiences influence tourists' intentions to engage in WOM communications. MTE components can have a positive effect on WOM intention. For example, the theoretical lens of SDL highlights the role of interactions for customer's involvement in WOM communications (Grissemann et al., 2013). Tourists who are more involved with a tourism firm/brand will likely build a relationship which goes beyond simple consumption (Rather et al., 2021). Service brands/firms including tourism destinations/sites are interested in encouraging WOM communications to attract and retain consumer traffic

PAGE 694 TOURISM REVIEW $\mid$ VOL. 77 NO. 22022 
(Gómez-Suárez and Veloso, 2020; Rather and Hollebeek, 2021). In view of this, the experience can promote the creation of WOM. By offering unforgettable, unique and memorable experiences, tourist destinations can attain brand promoters and co-creators of value via positive WOM recommendations (Gómez-Suárez and Veloso, 2020). Therefore, MTE (hedonism, novelty, local culture, refreshing, meaningfulness, involvement and knowledge) in a destination likely stimulates customer's WOM intention, as customers feel more satisfied while participating in value co-creation. Based on the above, the following hypotheses are proposed:

H4a. Hedonism has a positive effect on WOM intention.

H4b. Novelty has a positive effect on WOM intention.

H4c. Local Culture has a positive effect on WOM intention.

H4d. Refreshment has a positive effect on WOM intention.

H4e. Meaningfulness has a positive effect on WOM intention.

H4f. Involvement has a positive effect on WOM intention.

H4g. Knowledge has a positive effect on WOM intention.

H5a. Hedonism has a positive indirect effect on WOM intention through satisfaction.

H5b. Novelty has a positive indirect effect on WOM intention through satisfaction.

H5c. Local Culture has a positive indirect effect on WOM intention through satisfaction.

H5d. Refreshment has a positive indirect effect on WOM intention through satisfaction.

H5e. Meaningfulness has a positive indirect effect on WOM intention through satisfaction.

H5f. Involvement has a positive indirect effect on WOM intention through satisfaction.

H5g. Knowledge has a positive indirect effect on WOM intention through satisfaction.

\subsection{Satisfaction, word-of-mouth and revisit intention}

Satisfaction is one of the most influential drivers of behavioral intention, including revisit/ repurchase intention and WOM communications (Hollebeek and Rather, 2019). Satisfied consumers reveal a high predisposition to remain loyal to a brand/firm (Rather and Hollebeek, 2019). As the costs of acquiring new consumers are likely to be higher than retaining existing, tourism destinations and sites can sometimes struggle to build a loyal consumer base (Rather and Hollebeek, 2021). However, when consumers are more satisfied with their purchase, their re-purchase/revisit intention and recommendation propensity increase (Rasoolimanesh et al., 2019). Empirical confirmation suggests that satisfied consumers are likely to engage in revisit intention and WOM communications (Hollebeek and Rather, 2019). Therefore, the subsequent hypotheses are proposed as follows:

H6. Satisfaction has a positive effect on revisit intention.

H7. Satisfaction has a positive effect on WOM intention.

Figure 1 shows the conceptual framework of the current study.

\section{Research methodology}

\subsection{Study area}

Located in the northeastern province of Isfahan, Iran, the heritage city of Kashan represents one of the oldest continually inhabited cities of Iran and as UNESCO (2020) notes, is "an especial example of civilization from early Islamic period onward." Kashan has three major 


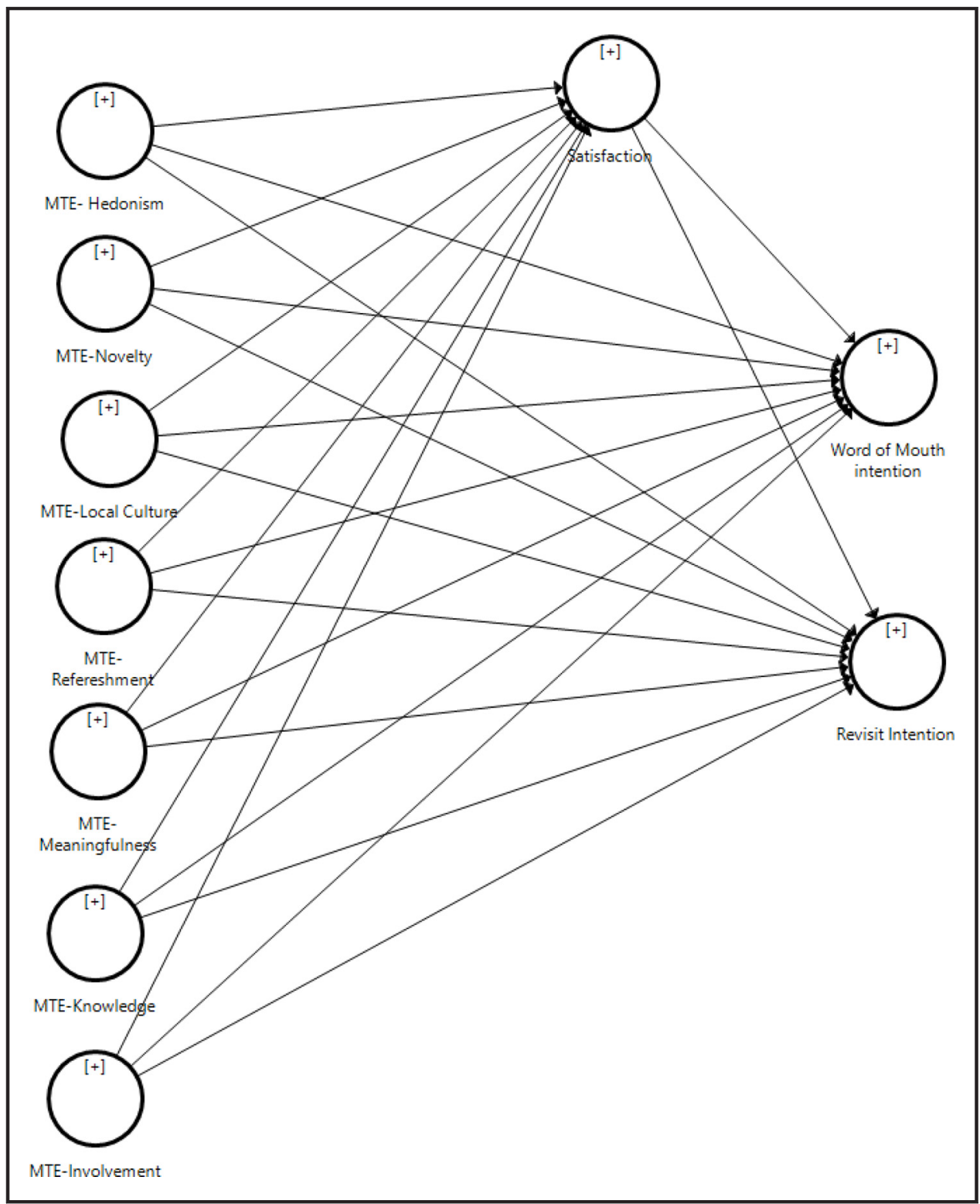

UNESCO-listed elements along with some tentatively listed elements and notable historical buildings and examples of traditional architecture (UNESCO, 2020). These have made the city of Kashan a major domestic and international heritage tourism destination pre-COVID19, the city attracted over one million domestic visitors per year and over 200,000 foreign tourists (Gannon et al., 2020).

\subsection{Data collection process}

This study applies a quantitative method using a self-administered questionnaire to collect data. The data were collected from domestic cultural tourists in selected heritage sites in Kashan, Iran, from May to August 2019. A non-probability purposive approach was applied to choose the samples and collect data. A total number of 409 questionnaires were 
collected, of which 350 were usable. Trained research assistants approached domestic tourists and briefly explained the purpose of the research and asked their willingness to participate in this study. If he/she was willing to participate, the questionnaire was given to her/him and collected, after completion. Out of 350 completed questionnaires, 204 were completed by male respondents and 146 by female tourists. The majority of respondents (63.4\%) were 18-38 years old and college or university graduates (55.4\%). Due to the long period of data collection and to check non-response bias, the early and late collected data were compared and no significant differences were detected (Gannon et al., 2020).

For this study, a questionnaire was developed based on previous studies. The items to measure seven components of MTE (e.g. hedonism, novelty, local culture, refreshment, meaningfulness, involvement and knowledge) were adapted from Kim et al. (2012) and Kim and Ritchie (2014), the items to measure satisfaction from Kim (2018), the items to measure revisit intention from Zhang et al. (2018) and Chen and Chen (2010) and WOM intention from Adongo et al. (2015) and Tsai (2016). The respondents were asked to answered the items to measure each construct using a five-point Likert scale with anchors ranging from 1 (strongly disagree) to 5 (strongly agree).

\subsection{Data analysis process}

This study applies both symmetric (e.g. PLS-SEM and asymmetric fsQCA) approaches to gain richer insights into the effects of components of MTE on satisfaction, revisit intention and WOM. The PLS-SEM has been applied because of the predictive nature and complexity of the model (Rasoolimanesh and Ali, 2018). To perform PLS-SEM, this study uses the SmartPLS 3.0 (Ringle et al., 2015) software package. To address the mediator, the product of the coefficients approach using bootstrapping has been applied (Gannon et al., 2020). The fsQCA has been applied in addition to PLS-SEM to obtain richer results and to identify sufficient configurations and causal combinations (Olya and Gavilyan, 2017) of components of MTE to generate tourists satisfaction, revisit intention and WOM. To perform fsQCA, the fsQCA 3.0 software was used to identify the sufficient causal combinations (i.e. configurations and recipes) of antecedents to generate outcomes (Rasoolimanesh et al., 2021). To identify the sufficient configurations, the consistency and coverage should be higher than 0.8 and 0.2, respectively, (Rasoolimanesh et al., 2020).

\section{Results}

\subsection{Assessment of the model using partial least squares-structural equation modeling}

The conceptual framework of this study contains 10 reflective constructs, namely, hedonism, novelty, local culture, refreshment, meaningfulness, involvement, knowledge, satisfaction, revisit intention and WOM intention. To assess the measurement model of reflective constructs, the loadings of items of each construct, the composite reliability (CR), the rho_A and the average variance extracted (AVE), is checked and the values of these parameters should be greater than $0.7,0.7,0.7$ and 0.5 , respectively, to establish the reliability and convergent validity (Ali et al., 2018). Table 1 shows the results of the assessment of the measurement model for 10 reflective constructs, indicating acceptable reliability and convergent validity for all constructs.

Table 2 shows the results of discriminant validity assessment using the conservative heterotrait-monotrait (HTMT) ratio approach (Rasoolimanesh and Ali, 2018). To establish discriminant validity the value of HTMT should be lower than 0.9 (Ali et al., 2018). The discriminant validity can be established based on the HTMT approach according to the results in Table 2. 
Table 1 Assessment of reflective measurement models

\begin{tabular}{|c|c|c|c|c|c|}
\hline Construct & Items & Loadings & $C R$ & rho_A & AVE \\
\hline Hedonism & $\begin{array}{l}\text { MHE1 } \\
\text { MHE2 } \\
\text { MHE3 } \\
\text { MHE4 }\end{array}$ & $\begin{array}{l}0.861 \\
0.874 \\
0.860 \\
0.875\end{array}$ & 0.924 & 0.894 & 0.752 \\
\hline Novelty & $\begin{array}{l}\text { MNO1 } \\
\text { MNO2 } \\
\text { MNO3 } \\
\text { MNO4 }\end{array}$ & $\begin{array}{l}0.655 \\
0.813 \\
0.821 \\
0.845\end{array}$ & 0.866 & 0.801 & 0.619 \\
\hline Local culture & $\begin{array}{l}\text { MLC1 } \\
\text { MLC2 } \\
\text { MLC3 }\end{array}$ & $\begin{array}{l}0.853 \\
0.838 \\
0.883\end{array}$ & 0.893 & 0.834 & 0.736 \\
\hline Refreshment & $\begin{array}{l}\text { MRE1 } \\
\text { MRE2 } \\
\text { MRE3 }\end{array}$ & $\begin{array}{l}0.814 \\
0.884 \\
0.891\end{array}$ & 0.898 & 0.830 & 0.746 \\
\hline Meaningfulness & $\begin{array}{l}\text { MME1 } \\
\text { MME2 } \\
\text { MME3 }\end{array}$ & $\begin{array}{l}0.818 \\
0.916 \\
0.893\end{array}$ & 0.908 & 0.862 & 0.768 \\
\hline Involvement & $\begin{array}{l}\text { MIN1 } \\
\text { MIN2 } \\
\text { MIN3 }\end{array}$ & $\begin{array}{l}0.858 \\
0.860 \\
0.840\end{array}$ & 0.889 & 0.815 & 0.727 \\
\hline Knowledge & $\begin{array}{l}\text { MKN1 } \\
\text { MKN2 } \\
\text { MKN3 }\end{array}$ & $\begin{array}{l}0.882 \\
0.891 \\
0.871\end{array}$ & 0.912 & 0.861 & 0.776 \\
\hline Satisfaction & $\begin{array}{l}\text { SAT1 } \\
\text { SAT2 } \\
\text { SAT3 }\end{array}$ & $\begin{array}{l}0.891 \\
0.865 \\
0.886\end{array}$ & 0.912 & 0.855 & 0.775 \\
\hline Revisit intention & $\begin{array}{l}\text { INT1 } \\
\text { INT2 } \\
\text { INT3 }\end{array}$ & $\begin{array}{l}0.927 \\
0.906 \\
0.861\end{array}$ & 0.926 & 0.886 & 0.807 \\
\hline $\begin{array}{l}\text { WOM intention } \\
\text { Intention (WOM) }\end{array}$ & $\begin{array}{l}\text { WOM1 } \\
\text { WOM2 } \\
\text { WOM3 } \\
\text { WOM4 } \\
\text { WOM5 } \\
\text { WOM6 }\end{array}$ & $\begin{array}{l}0.826 \\
0.832 \\
0.854 \\
0.562 \\
0.590 \\
0.511\end{array}$ & 0.854 & 0.888 & 0.505 \\
\hline
\end{tabular}

Table 3 shows the results of hypothesis testing. The results can support the significant effects of Local Culture $(H 1 C)$, Involvement $(H 1 f)$, Knowledge $(H 1 g)$ on satisfaction, whereas the effects of other components of MTE on satisfaction are either insignificant (H1a, H1b and $\mathrm{H}_{1 \mathrm{~d}}$ ) or negative $(\mathrm{H} 1 \mathrm{e})$ and different with the sign of hypothesis and cannot be supported. The second set of hypotheses in Table 3 show the direct effect of MTE components on revisit intention, which only one direct effect (Local Culture - H2C) is significant and the direct effects of other components on revisit intention are not significant (H2a, H2b, H2d, H2e, H2f and H2g). However, for the indirect effects of componentson revisit intention through satisfaction, three hypotheses can be supported $(\mathrm{H} 3 \mathrm{C}, \mathrm{H} 3 \mathrm{f}$ and $\mathrm{H} 1 \mathrm{~g})$ 
Table 2 Discriminant validity using HTMT ratio

\begin{tabular}{|c|c|c|c|c|c|c|c|c|c|c|}
\hline Constructs & MHE & MNO & $M L C$ & $M R E$ & MME & MIN & $M K N$ & SAT & INT & WOM \\
\hline \multicolumn{11}{|l|}{ MHE } \\
\hline MNO & 0.833 & & & & & & & & & \\
\hline MLC & 0.485 & 0.738 & & & & & & & & \\
\hline MRE & 0.570 & 0.726 & 0.767 & & & & & & & \\
\hline MME & 0.560 & 0.632 & 0.495 & 0.805 & & & & & & \\
\hline MIN & 0.512 & 0.666 & 0.683 & 0.714 & 0.637 & & & & & \\
\hline MKN & 0.524 & 0.627 & 0.576 & 0.673 & 0.845 & 0.771 & & & & \\
\hline SAT & 0.415 & 0.597 & 0.674 & 0.557 & 0.425 & 0.852 & 0.608 & & & \\
\hline INT & 0.427 & 0.592 & 0.699 & 0.596 & 0.538 & 0.730 & 0.653 & 0.821 & & \\
\hline WOM & 0.437 & 0.556 & 0.466 & 0.508 & 0.480 & 0.513 & 0.506 & 0.543 & 0.710 & \\
\hline
\end{tabular}

Table 3 Results of hypothesis testing

\begin{tabular}{|c|c|c|c|c|c|}
\hline & Hypothesis & $\begin{array}{c}\text { Direct/ } \\
\text { indirect effect }\end{array}$ & $P$-value & $\begin{array}{l}95 \% \text { Bias corrected } \\
\text { confidence interval }\end{array}$ & Supported \\
\hline H1a & Hedonism $\rightarrow$ satisfaction & -0.010 & 0.441 & {$[-0.125,0.90]$} & No \\
\hline$H 1 b$ & Novelty $\rightarrow$ satisfaction & 0.095 & 0.124 & {$[-0.040,0.231]$} & No \\
\hline$H 1 \mathrm{C}$ & Local culture $\rightarrow$ satisfaction & 0.207 & 0.002 & {$[0.088,0.320]$} & Yes \\
\hline H1d & Refreshment $\rightarrow$ satisfaction & -0.003 & 0.485 & {$[-0.134,0.138]$} & No \\
\hline H1e & Meaningfulness $\rightarrow$ satisfaction & -0.206 & 0.019 & {$[-0.375,-0.048]$} & No (different sign) \\
\hline H1f & Involvement $\rightarrow$ satisfaction & 0.530 & 0.000 & {$[0.378,0.665]$} & Yes \\
\hline H1g & Knowledge $\rightarrow$ satisfaction & 0.204 & 0.024 & {$[0.040,0.380]$} & Yes \\
\hline $\mathrm{H} 2 \mathrm{a}$ & Hedonism $\rightarrow$ revisit intention & 0.002 & 0.486 & {$[-0.084,0.080]$} & No \\
\hline $\mathrm{H} 2 \mathrm{~b}$ & Novelty $\rightarrow$ revisit intention & 0.009 & 0.452 & {$[-0.117,0.135]$} & No \\
\hline $\mathrm{H} 2 \mathrm{C}$ & Local Culture $\rightarrow$ revisit intention & 0.214 & 0.018 & {$[0.049,0.387]$} & Yes \\
\hline $\mathrm{H} 2 \mathrm{~d}$ & Refreshment $\rightarrow$ revisit intention & -0.005 & 0.472 & {$[-0.135,0.107]$} & No \\
\hline $\mathrm{H} 2 \mathrm{e}$ & Meaningfulness $\rightarrow$ revisit intention & 0.088 & 0.129 & {$[-0.032,0.220]$} & No \\
\hline $\mathrm{H} 2 \mathrm{f}$ & Involvement $\rightarrow$ revisit intention & 0.120 & 0.109 & {$[-0.039,283]$} & No \\
\hline $\mathrm{H} 2 \mathrm{~g}$ & Knowledge $\rightarrow$ revisit intention & 0.043 & 0.336 & {$[-0.125,0.208]$} & No \\
\hline $\mathrm{H} 3 \mathrm{a}$ & Hedonism $\rightarrow$ satisfaction $\rightarrow$ revisit intention & -0.005 & 0.442 & {$[-0.063,0.40]$} & No \\
\hline$H 3 b$ & Novelty $\rightarrow$ satisfaction $\rightarrow$ revisit intention & 0.044 & 0.141 & {$[-0.016,0.119]$} & No \\
\hline $\mathrm{H} 3 \mathrm{C}$ & Local culture $\rightarrow$ satisfaction $\rightarrow$ revisit intention & 0.097 & 0.006 & {$[0.043,0.171]$} & Yes \\
\hline$H 3 d$ & Refreshment $\rightarrow$ satisfaction $\rightarrow$ revisit intention & -0.001 & 0.485 & {$[-0.064,0.067]$} & No \\
\hline $\mathrm{H} 3 \mathrm{e}$ & Meaningfulness $\rightarrow$ satisfaction $\rightarrow$ revisit intention & -0.096 & 0.028 & {$[-0.193,-0.027]$} & No (different sign) \\
\hline H3f & Involvement $\rightarrow$ satisfaction $\rightarrow$ revisit intention & 0.247 & 0.000 & {$[0.156,0.356]$} & Yes \\
\hline$H 3 g$ & Knowledge $\rightarrow$ satisfaction $\rightarrow$ revisit intention & 0.095 & 0.034 & {$[0.024,0.197]$} & Yes \\
\hline $\mathrm{H} 4 \mathrm{a}$ & Hedonism $\rightarrow$ WOM intention & 0.035 & 0.309 & {$[-0.085,0.150]$} & No \\
\hline$H 4 b$ & Novelty $\rightarrow$ WOM intention & 0.191 & 0.017 & {$[0.038,0.333]$} & Yes \\
\hline $\mathrm{H} 4 \mathrm{C}$ & Local Culture $\rightarrow$ WOM intention & -0.004 & 0.487 & {$[-0.183,0.180]$} & No \\
\hline $\mathrm{H} 4 \mathrm{~d}$ & Refreshment $\rightarrow$ WOM intention & 0.063 & 0.240 & {$[-0.087,0.198]$} & No \\
\hline $\mathrm{H} 4 \mathrm{e}$ & Meaningfulness $\rightarrow$ WOM intention & 0.098 & 0.169 & {$[-0.068,0.226]$} & No \\
\hline$H 4 f$ & Involvement $\rightarrow$ WOM intention & -0.004 & 0.486 & {$[-0.206,0.197]$} & No \\
\hline $\mathrm{H} 4 \mathrm{~g}$ & Knowledge $\rightarrow$ WOM intention & 0.017 & 0.437 & {$[-0.156,0.193]$} & No \\
\hline $\mathrm{H} 5 \mathrm{a}$ & Hedonism $\rightarrow$ satisfaction $\rightarrow$ WOM intention & -0.004 & 0.442 & {$[-0.053,0.038]$} & No \\
\hline$H 5 b$ & Novelty $\rightarrow$ satisfaction $\rightarrow$ WOM intention & 0.039 & 0.137 & {$[-0.013,0.106]$} & No \\
\hline $\mathrm{H} 5 \mathrm{C}$ & Local culture $\rightarrow$ satisfaction $\rightarrow$ WOM intention & 0.085 & 0.011 & {$[0.035,0.159]$} & Yes \\
\hline$H 5 d$ & Refreshment $\rightarrow$ satisfaction $\rightarrow$ WOM intention & -0.001 & 0.485 & {$[-0.059,0.057]$} & No \\
\hline $\mathrm{H} 5 \mathrm{e}$ & Meaningfulness $\rightarrow$ satisfaction $\rightarrow$ WOM intention & -0.085 & 0.037 & {$[-0.179,-0.021]$} & No (different sign) \\
\hline$H 5 f$ & Involvement $\rightarrow$ satisfaction $\rightarrow$ WOM intention & 0.218 & 0.000 & {$[0.125,0.334]$} & Yes \\
\hline$H 5 g$ & Knowledge $\rightarrow$ satisfaction $\rightarrow$ WOM intention & 0.084 & 0.044 & {$[0.021,0.187]$} & Yes \\
\hline$H 6$ & Satisfaction $\rightarrow$ revisit intention & 0.466 & 0.000 & {$[0.315,0.610]$} & Yes \\
\hline$H 7$ & Satisfaction $\rightarrow$ WOM intention & 0.411 & 0.000 & {$[0.243,0.564]$} & Yes \\
\hline
\end{tabular}


and similar to the effects on satisfaction, $\mathrm{H} 3 \mathrm{a}, \mathrm{H} 3 \mathrm{~b}$ and $\mathrm{H} 3 \mathrm{~d}$ are insignificant and $\mathrm{H} 3 \mathrm{e}$ cannot be supported. Therefore, the results highlight the importance of Local Culture, Involvement and Knowledge to generate satisfaction and revisit the intention of domestic tourists.

For the direct effects of the dimension of MTE on WOM intention, the results only show the significant effect of Novelty (H4b) on WOM intention, whereas the indirect effects through satisfaction are similar to revisit intention. For the indirect effects of components through satisfaction, the Local Culture (H5c), Involvement (H5f), Knowledge $(\mathrm{H} 5 \mathrm{~g})$ have significant indirect effects, whereas the indirect effect of Meaningfulness $(\mathrm{H} 5 \mathrm{e})$ is negative and the effects of Hedonism ( $\mathrm{H} 5 \mathrm{a})$, Novelty $(\mathrm{H} 5 \mathrm{~b})$ and Refreshment $(H 5 d)$ are not significant. The results show positive and strong effects of satisfaction on revisit intention $(H 6)$ and WOM intention( $H 7)$.

\subsection{Results of fuzzy-set qualitative comparative analysis}

Tables $4-6$, show the results of fsQCA and sufficient causal configurations to generate a high level of satisfaction, revisit intention and WOM intention, respectively. The fsQCA is an asymmetric approach, which identifies sufficient and necessary combinations of predictors to generate a high level of outcome. The results of fsQCA show similar sufficient configurations for three outcomes (e.g. satisfaction, revisit intention and WOM intention) of this study. The results show four causal combinations (i.e. configurations or recipes) including as follows:

Configuration 1: Hedonism* Knowledge* Local Culture* Novelty * Refreshment; Configuration 2: Hedonism ${ }^{*} \sim$ Involvement ${ }^{*} \sim$ Knowledge $* \sim$ Local Culture $*$ Meaningfulness $* \sim$ Refreshment,

Configuration 3: $\sim$ Involvement $*$ Knowledge $*$ Local Culture $*$ Meaningfulness $*$ Novelty $* \sim$ Refreshment and Configuration 4: $\sim$ Hedonism $*$ Involvement ${ }^{*}$ Knowledge ${ }^{*}$ Local Culture $*$

Table 4 Sufficient causal configurations for satisfaction

Configurations

Raw coverage

Unique coverage

Consistency

Configurations for high satisfaction

Satisfaction = $\mathrm{f}(\mathrm{MHE} ; \mathrm{MNO}$; MLC; MRE; MME; MIN; MKN)

MHE* MKN* MLC* MNO*MRE

$\mathrm{MHE}^{*} \sim \mathrm{MINV}^{*} \sim \mathrm{MKN}^{*} \sim \mathrm{MLC}^{*} \sim \mathrm{MME}^{*} \sim \mathrm{MRE}$

0.689

0.177

0.951

$\sim \mathrm{MINV}^{*} \sim \mathrm{MKN}^{*} \sim \mathrm{MLC}^{*} \sim \mathrm{MME}^{*} \mathrm{MNO}^{*} \sim \mathrm{MRE}$

0.511

0.146

0.923

$\sim \mathrm{MHE}^{*} \mathrm{MINV}^{*} \mathrm{MKN}^{*} \mathrm{MLC}^{*} \sim \mathrm{MME}^{*} \mathrm{MRE}$

0.519

0.009

0.932

solution coverage: 0.784

0.546

0.029

0.990

solution consistency: 0.899

Notes: Hedonism = MHE; Novelty = MNO; Local culture = MLC; Refreshment = MRE; Meaningfulness = MME; Involvement = MIN; Knowledge $=$ MKN

\section{Table 5 Sufficient causal configurations for revisit intention}

Configurations for high revisit intention

Revisit Intention = $f(M H E ; M N O ; M L C ; M R E ; M M E ; M I N ; M K N)$

0.703

0.516

0.528

$\sim \mathrm{MINV}^{*} \sim \mathrm{MKN}^{*} \sim \mathrm{MLC}^{*} \sim \mathrm{MME}^{*} \mathrm{MNO}^{*} \sim \mathrm{MRE}$

$\sim \mathrm{MHE}^{*} \mathrm{MINV}^{*} \mathrm{MKN}^{*} \mathrm{MLC}^{*} \sim \mathrm{MME}^{*} \mathrm{MRE}$

solution coverage: 0.795

solution consistency: 0.903

Notes: Hedonism = MHE; Novelty = MNO; Local culture = MLC; Refreshment = MRE; Meaningfulness = MME; Involvement = MIN; Knowledge $=$ MKN 
Table 6 Sufficient causal configurations for word of mouth intention

Configurations

Raw coverage

Unique coverage

Consistency

Configurations for high WOM intention

WOM $=f(M H E ; M N O ; M L C ; M R E ; M M E ; M I N ; M K N)$

$\mathrm{MHE}^{*} \mathrm{MKN}^{*} \mathrm{MLC}^{*} \mathrm{MNO}^{*} \mathrm{MRE}$

0.695

0.514

0.525

0.180

0.957

$\mathrm{MHE}^{*} \sim \mathrm{MINV}^{*} \sim \mathrm{MKN}^{*} \sim \mathrm{MLC}^{*} \sim \mathrm{MME}^{*} \sim \mathrm{MRE}$

0.013

0.926

$\sim \mathrm{MINV}^{*} \sim \mathrm{MKN}^{*} \sim \mathrm{MLC}^{*} \sim \mathrm{MME}^{*} \mathrm{MNO}^{*} \sim \mathrm{MRE}$

0.538

0.010

0.940

$\sim \mathrm{MHE}^{*} \mathrm{MINV}^{*} \mathrm{MKN}^{*} \mathrm{MLC}^{*} \sim \mathrm{MME}^{*} \mathrm{MRE}$

0.021

0.973

solution coverage: 0.784

solution consistency: 0.897

Notes: Hedonism = MHE; novelty = MNO; local culture = MLC; refreshment = MRE; meaningfulness = MME; involvement $=$ MIN knowledge $=$ MKN

Meaningfulness * Refreshment to generate high levels of satisfaction, revisit intention and WOM intention. The first configuration shows the combination of Hedonism, Novelty, Local Culture, Refreshment and Knowledge as a sufficient combination to generate high levels of satisfaction, revisit intention and loyalty. Therefore, when tourists experience a high level of these components simultaneously, their satisfaction, WOM intention and loyalty will be high. This configuration highlights some differences with the results of PLS-SEM, which showed only the significant effects of Local Culture, Involvement and Knowledge on satisfaction, revisit intention and WOM intention. Moreover, the rest of the sufficient configurations highlight various combinations to generate a high level of satisfaction, revisit intention and WOM intention. With only the high level of Hedonism (Configuration 2) and Novelty (Configuration 3) and low levels of Involvement, Knowledge, Local Culture, Meaningfulness and Refreshment, high levels of satisfaction, revisit intention and WOM intention can be generated. In addition, based on configuration 4, the high levels of Knowledge, Local Culture, Involvement and Refreshment, with low levels of Hedonism and Meaningfulness can generate high levels of satisfaction, revisit intention and WOM intention. Therefore, based on the results of fsQCA, we can observe more heterogenous combinations of components of MTE to generate a high level of satisfaction, revisit intention and WOM intention compared to the results of the symmetric PLS-SEM approach.

\section{Discussion}

This study sought to investigate the effects of MTE components on revisit and WOM intentions of heritage tourists through the mediating role of satisfaction. In doing so, this study responds to tourism researchers' calls for more scholarly and context-based studies into MTE (Hung et al., 2016; Rasoolimanesh et al., 2021) by applying the seminal MTE scale developed by Kim et al. (2012) into heritage tourism setting. To obtain a deeper understanding, the effects of MTE components on outcomes (e.g. revisit and WOM intention) are examined using two different methods (PLS-SEM and fSQCA). The findings of this study do not fully validate those of Kim et al. (2012) but demonstrate different effects of MTE components on satisfaction and behavioral intentions. The synthesis of the results indicates that only local culture, involvement and knowledge have a significant impact on satisfaction, which is aligned with the findings of Gohary et al. (2020) and Kim et al. (2010). The findings of the study contradict the assumption that the seven components of MTE are indicative of a range of destination-specific tourist experiences (Sthapit et al., 2019).

The results of symmetric PLS-SEM showed the significant effects of Local Culture, Involvement, Knowledge on satisfaction, revisit and WOM intentions either directly or indirectly consistent with previous studies (Kim et al., 2012; Tung and Ritchie, 2011a; Kim and Ritchie, 2014). The importance of social interactions between tourists and local culture at a destination is widely acknowledged as a significant aspect of the memorability of the tourist experience (Morgan and Xu, 2009; Kim et al., 2012). This indicates that travelers with 
higher levels of involvement and knowledge about local culture, residents' way of life and destination language gained through interactions with the host community are more likely to revisit in the future.

In addition, the results only showed the significant direct effect of Novelty on WOM intention and not the indirect effect. The rationale is that many tourists have an inherent need for novelty in deciding to visit a destination. Novel experiences at a destination are a key input for memories (Kim et al., 2010), which influences tourists' future decision-making processes. Other scales have been suggested for better predicting tourist behavioral intent than novelty seeking, such as a scale formed by joy, love and positive surprise (Hosany and Gilbert, 2010).

The results also showed the surprising negative direct effect of Meaningfulness on satisfaction and indirect effects on revisit and WOM intention. However, as these findings attest, a meaningful experience may not necessarily lead to positive WOM communications which are inconsistent with previous studies (Gohary et al., 2020; Sthapit et al., 2017). Although meaningfulness appears important for tourist's well-being or happiness (Baumeister and Vohs, 2002), individuals may struggle to obtain meaning in their lives (Tung and Ritchie, 2011a). Consequently, people may search for meaningful experiences in their tourism and travel activities, by seeking a sense of emotional-, physical- or spiritualfulfillment (Kim and Ritchie, 2014). For instance, it has long been recognized that some people view a tourism-experience as an inner journey for self-development and personal growth, rather than just being material consumption or social commoditization (Tsiotsou and Goldsmith, 2012; Tung and Ritchie, 2011a).

The results of PLS-SEM could not support the effects of Hedonism and Refreshment on satisfaction, revisit and WOM intention and the effects of Novelty on satisfaction and revisit intention. This is again surprising as the desire to seek hedonic experiences, such as excitement and pleasure and novelty seeking are popular leisure travel motivators (Dunman and Mattila, 2005), fundamental factors in tourism experiences (Otto and Ritchie, 1996) and a key factor in post-travel evaluation (Dunman and Mattila, 2005). Various superstructures, events or activities in a destination/site can satisfy tourist's desires for novelty and hedonism. This reflects Kim et al. (2012) and Kim's (2014) notions that both negative- and positive- experiences (e.g. excitement and pleasure) are memorable, although certain negative aspects of destinations can likely cause negative feelings (e.g. anger or frustration) that affect the development of negativememorable experiences. Unsatisfactory destination management or poor destination accessibility also influenced the creation of negative-based memorable experiences.

The results of fsQCA showed more heterogenous sufficient combinations of components of MTE to generate high levels of satisfaction, revisit and WOM intention. According to the results of fsQCA, high levels of knowledge, local culture, involvement, consistent with PLSSEM results can generate high levels of satisfaction, revisit and WOM intention. The rationale is that understanding and exploring local cultures, meeting local residents and learning about local culture and active involvement of tourists with such travel experiences construct a unique and memorable holiday experience for travelers which significantly enhances MTE (Tung and Ritchie, 2011a). However, fsQCA results also highlighted the importance of Hedonism and Novelty components, which generate high levels of satisfaction, revisit and WOM intention, even when the levels of other components of MTE are low. These findings are consistent with some previous studies (Coudounaris and Sthapit, 2017; Kim and Ritchie, 2014).

\section{Conclusions}

\subsection{Theoretical contributions}

This study has generated results that may contribute to the theoretical enrichment of MTE.

First, it contributes to the tourism literature by testing Kim et al. (2012) MTE scale in a new

PAGE 702 | TOURISM REVIEW $\mid$ VOL. 77 NO. 22022 
tourism context and offers a new perspective on the interrelationships between the components of MTE and behavioral intentions of heritage tourists. The latter has been highlighted by several tourism researchers (Chandralal and Valenzuela, 2015; Hung et al., 2016; Rasoolimanesh et al., 2021), who called for further academic inquiries to enrich understanding of MTE. The construction and testing of this seminal scale in a different context contribute to a better and broader understanding of the associations between MTE components and subsequent behavioral intentions.

Second, merging PLS-SEM with fSQCA provided several new insights. The findings of this study do not fully validate those of Kim et al. (2012) but demonstrate different impacts of MTE components on behavioral intent. This emphasizes the context-based and highly destination specific feature and focus of MTE.

Third, testing and highlighting the mediating role of satisfaction for the effects of MTE components on revisit and WOM intention in heritage tourism, which has been overlooked in prior studies, is another theoretical contribution of this paper. Despite Kim's (2010) finding that satisfying tourism experiences are unlikely to be remembered in the post-consumption phase with no further competitive advantage offered to destination businesses, the findings of this study suggest that the higher the degree of tourist satisfaction, the higher the memorability for the tourist.

\subsection{Practical implications}

This study has several practical implications. The findings provide a useful framework for destinations wishing to establish or improve MTE and emphasize the role of MTE. The study's first managerial implication is that to enable sustainable competitive advantage, Destination Marketing Organization (DMOs) should be directed to rely on the essential roles of MTE and positive sentiment rather than just focusing on product-oriented marketing. As the findings showed, to improve the memorability of a destination, the dimensions of MTE including local culture, involvement and knowledge has a critical direct effect on satisfaction. As a result, DMOs in Kashan or in a similar heritage context need to emphasize these components by providing more opportunities for visitors to stay with locals. The role of local tour guides is also important in offering information and knowledge about the city and its attractions. Overall, as the findings highlighted, the richest experiences affect the future decisions of consumers and behavior and are often the most reliable source of information in revisit intention and WOM communications. This is of particular significance for DMOs and tourism businesses seeking to enhance the memorability of visitors' experiences. Furthermore, as the results highlighted the dimension of "local culture" in the MTE scale directly affects revisit intention. Tourism service provides and DMOs should attach importance to this by providing authentic local experiences for tourists and emphasize the memorability of this component. For instance, the Rose Water festival was among the most noted experiences of respondents and this can provide an opportunity where tourists to participate in local activities in an effort to generate MTE. Based on the results of research DMOs could also offer new and creative activities in which individuals can closely experience local culture. In the case of Kashan and potentially similar destinations, evidence suggests that this may mean gastronomic experiences, co-creating souvenir making with handicrafts and staying in traditional guesthouses. By offering such cultural activities, memorable experiences could be shared by tourists with others thereby potentially encouraging revisitation. The higher co-creation between tourists and local people during an on-site destination experience may also lead to greater memorability of the trip.

\subsection{Limitations and directions for future research}

The study has several limitations which provide avenues for future research. First, the questionnaires were distributed to visitors on site. In contrast to previous studies 
(Chandralal and Valenzuela, 2015; Kim and Ritchie, 2014; Tung and Ritchie, 2011a) that asked respondents to recall their most memorable recent tourism experience our respondents were surveyed immediately after or during their visit to Kashan. Although such an approach probably allowed respondents to have a better memory of their experience and increase recall precision, compared with the post-visit approach, it is suggested for future studies to focus on the former approach to better capture post-trip behavior, ideally within an extended research framework. It has also been long recognized that surveying respondents well after their visit when in their home environment may identify understandings of memorable experiences that did not exist during the initial visit or just after (Andressen and Hall, 1988,1989). Second, to measure MTE, our study was built on the framework developed by Kim et al. (2012) and tourists' positive MTE were only investigated and negative MTE components were not reflected in our study. Negative experiences which result in undesirable future behaviors can also generate distinct and memorable experiences (Kim et al., 2020; Sthapit et al., 2020). Thus, a comprehensive questionnaire covering positive and negative components related to experiences is suggested for future study on the topic. Third, this study focuses on visitors in a heritage site. Future studies are suggested to investigate our integrated framework of influencing factors on revisit and WOM intention in other tourism contexts post-COVID-19. Fourth, this study has focused on domestic visitors. Future studies could focus on both domestic and international tourists through a comparative study.

\section{References}

Abraham, V. and Poria, Y. (2020), "Perceptions of a heritage site and animosity: the case of the West Bank", Tourism Review, Vol. 75 No. 5.

Ali, F., Ryu, K. and Hussain, K. (2016), "Influence of experiences on memories, satisfaction and behavioral intentions: a study of creative tourism", Journal of Travel \& Tourism Marketing, Vol. 33 No. 1, pp. 85-100.

Ali, F., Rasoolimanesh, S.M., Sarstedt, M., Ringle, C.M. and Ryu, K. (2018), "An assessment of the use of partial least squares structural equation modeling (PLS-SEM) in hospitality research", International Journal of Contemporary Hospitality Management, Vol. 30 No. 1, pp. 514-538.

Andrades, L. and Dimanche, F. (2014), "Co-creation of experience value: a tourist behaviour approach", in Chen, M. and Uysal, J. (Eds), Creating Experience Value in Tourism, CABI, Wallingford, pp. 95-112.

Andressen, B. and Hall, M. (1988/89), "The importance of intense negative outdoor experiences", Recreation Australia, Vol. 8 No. 1, pp. 6-8.

Assaker, G., Vinzi, V.E. and O'Connor, P. (2011), "Examining the effect of novelty seeking, satisfaction, and destination image on tourists' return pattern: a two factor, non-linear latent growth model", Tourism Management, Vol. 32 No. 4, pp. 890-901.

Babu, P. and Bibin, P. (2004), "Past visits and the intention to revisit a destination: place attachment as the mediator and novelty seeking as the moderator", Journal of Tourism Studies, Vol. 15 No. 2, pp. 51-66.

Baumeister, R.F. and Vohs, K.D. (2002), "The pursuit of meaningfulness in life", in Snyder, C.R. and Lopez, S.J. (Eds), Handbook of Positive Psychology, New York: Oxford University Press, pp. 608-618.

Bigné, J.E., Andreu, L. and Gnoth, J. (2005), "The theme park experience: an analysis of pleasure, arousal and satisfaction", Tourism Management, Vol. 26 No. 6, pp. 833-844.

Chandralal, L. and Valenzuela, F.R. (2015), "Memorable tourism experiences: scale development", Contemporary Management Research, Vol. 11 No. 3, pp. 291-310.

Chang, E., Burns, L.D. and Francis, S.K. (2004), "Gender differences in the dimensional structure of apparel shopping satisfaction among Korean consumers: the role of hedonic shopping value", Clothing and Textiles Research Journal, Vol. 22 No. 4, pp. 185-199.

Chen, C.F. and Chen, F.S. (2010), "Experience quality, perceived value, satisfaction and behavioral intentions for heritage tourists", Tourism Management, Vol. 31 No. 1, pp. 29-35.

Chen, N.C., Hall, C.M. and Prayag, G. (2021), Sense of Place and Place Attachment in Tourism, Routledge, Abingdon. 
Chen, X., Cheng, Z.F. and Kim, G.B. (2020), "Make it memorable: tourism experience, fun, recommendation and revisit intentions of Chinese outbound tourists", Sustainability, Vol. 12 No. 5, pp. 1-24.

Cho, H., Tan, K.M. and Chiu, W. (2020), "Will I be back? Evoking nostalgia through college students' memorable exchange programme experiences", Tourism Review, Vol. 76 No. 2, pp. 392-410.

Clements, C.J. and Josiam, B. (1995), "Role of involvement in the travel decision", Journal of Vacation Marketing, Vol. 1 No. 4, pp. 337-348.

Cohen, E. (1979), "A phenomenology of tourist experiences”, Sociology, Vol. 13 No. 2, pp. 179-201.

Coudounaris, D.N. and Sthapit, E. (2017), "Antecedents of memorable tourism experience related to behavioral intentions", Psychology and Marketing, Vol. 34 No. 12, pp. 1084-1093.

Dunman, T. and Mattila, A.S. (2005), "The role of affective factors on perceived cruise vacation value", Tourism Management, Vol. 26 No. 3, pp. 311-323.

Gannon, M., Rasoolimanesh, S.M. and Taheri, B. (2020), "Assessing the mediating role of residents' perceptions toward tourism development”, Journal of Travel Research, Vol. 60 No. 1, pp. 149-171.

Garrod, B. and Fyall, A. (2000), "Managing heritage tourism”, Annals of Tourism Research, Vol. 27 No. 3 , pp. 682-708.

Garrod, B. and Fyall, A. (2001), "Heritage tourism: a question of definition", Annals of Tourism Research, Vol. 28 No. 4, pp. 1049-1052.

Gohary, A., Pourazizi, L., Madani, F. and Chan, E.Y. (2020), "Examining Iranian tourists memorable experiences on destination satisfaction and behavioral intentions", Current Issues in Tourism, Vol. 23 No. 2, pp. 131-136.

Grissemann, U., Plank, A. and Brunner-Sperdin, A. (2013), "Enhancing business performance of hotels: the role of innovation and customer orientation", International Journal of Hospitality Management, Vol. 33, pp. 347-356.

Gómez-Suárez, M. and Veloso, M. (2020), "Brand experience and brand attachment as drivers of WOM in hospitality", Spanish Journal of Marketing-ESIC, Forthcoming.

Hall, M. and Zeppel, H. (1990), "Cultural and heritage tourism: the new grand tour", Historic Environment, Vol. 7 Nos 3/4, pp. 86-98.

Hargrove, C. (2002), “Heritage tourism”, Cultural Resource Management, Vol. 25 No. 1, pp. 10-11.

Holbrook, M. and Hirschman, E. (1982), "The experiential aspects of consumption -consumer fantasies, feelings, and fun”, Journal of Consumer Research, Vol. 9 No. 2, pp. 132-140.

Hollebeek, L. and Rather, R. (2019), "Service innovativeness and tourism customer outcomes", International Journal of Contemporary Hospitality Management, Vol. 31 No. 11, pp. 4227-4246.

Hosany, S. and Gilbert, D. (2010), "Measuring tourists' emotional experiences toward hedonic holiday destinations", Journal of Travel Research, Vol. 49 No. 4, pp. 513-526.

Hung, K. and Petrick, J.F. (2011), "Why do you cruise? Exploring the motivations for taking cruise holidays, and the construction of a cruising motivation scale", Tourism Management, Vol. 32 No. 2, pp. 386-393.

Hung, W.L., Lee, Y.J. and Huang, P.H. (2016), "Creative experiences, memorability and revisit intention in creative tourism", Current Issues in Tourism, Vol. 19 No. 8, pp. 763-770.

Kim, J.H. (2010), "Determining the factors affecting the memorable nature of travel experiences", Journal of Travel \& Tourism Marketing, Vol. 27 No. 8, pp. 780-796.

Kim, J.H. (2014), "The antecedents of memorable tourism experiences: the development of a scale to measure the destination attributes associated with memorable experiences", Tourism Management, Vol. 44, pp. 34-45.

Kim, J.H. (2018), "The impact of memorable tourism experiences on loyalty behaviors: the mediating effects of destination image and satisfaction", Journal of Travel Research, Vol. 57 No. 7, pp. 856-870.

Kim, J.H. and Ritchie, J.R.B. (2014), "Cross-cultural validation of a memorable tourism experience scale (MTES)", Journal of Travel Research, Vol. 53 No. 3, pp. 323-335. 
Kim, J.H., Ritchie, J.B. and McCormick, B. (2012), "Development of a scale to measure memorable tourism experiences", Journal of Travel Research, Vol. 51 No. 1, pp. 12-25.

Kim, J.H., Ritchie, J.R. and Tung, V.W.S. (2010), "The effect of memorable experience on behavioral intentions in tourism: a structural equation modeling approach", Tourism Analysis, Vol. 15 No. 6, pp. 637-648.

Lee, Y.J. (2015), "Creating memorable experiences in a reuse heritage site", Annals of Tourism Research, Vol. 55, pp. 155-170.

Lee, T.H. and Crompton, J. (1992), "Measuring novelty seeking in tourism", Annals of Tourism Research, Vol. 19 No. 4, pp. 732-751.

Lim, W.M. (2014), "The antecedents and consequences of customer hedonism in hospitality services", Journal of Hospitality Marketing \& Management, Vol. 23 No. 6, pp. 626-651.

Mgxekwa, B.B., Scholtz, M. and Saayman, M. (2017), "Creating a memorable experience for Nelson mandela heritage site visitors", African Journal of Hospitality, Tourism and Leisure, Vol. 6 No. 1, pp. 1-16.

Marschall, S. (2012), "'Personal memory tourism' and a wider exploration of the tourism memory nexus", Journal of Tourism and Cultural Change, Vol. 10 No. 4, pp. 321-335.

Morgan, M. and Xu, F. (2009), "Student travel experiences: memories and dreams", Journal of Hospitality Marketing \& Management, Vol. 18 No. 2-3, pp. 216-236.

Oh, H., Fiore, A.M. and Jeoung, M. (2007), "Measuring experience economy concepts: tourism applications", Journal of Travel Research, Vol. 46 No. 2, pp. 119-132.

Otto, J. and Ritchie, J. (1996), "The service experience in tourism”, Tourism Management, Vol. 17 No. 3 , pp. $165-174$.

Oliver, R.L. (1980), "A cognitive model of the antecedents and consequences of satisfaction decisions", Journal of Marketing Research, Vol. 17 No. 4, pp. 460-469.

Oliver, R.L. (1997), Satisfaction: A Behavioral Perspective on the Consumer, McGraw-Hill, New York, NY.

Olya, H.G. and Gavilyan, Y. (2017), "Configurational models to predict residents' support for tourism development”, Journal of Travel Research, Vol. 56 No. 7, pp. 893-912.

Pearce, D.G. (1987), Tourism Today: A Geographical Analysis, Longman, Harlow.

Pine, B.J. and Gilmore, J.H. (1998), "Welcome to the experience economy", Harvard Business Review, Vol. 76 No. 4, pp. 97-105.

Rasoolimanesh, S.M., Seyfi, S., Hall, C.M. and Hatamifar, P. (2021), "Understanding memorable tourism experiences and behavioural intentions of heritage tourists", Journal of Destination Marketing \& Management, Vol. 21, p. 100621.

Rasoolimanesh, S.M. and Ali, F. (2018), "Partial least squares-structural equation modeling in hospitality and tourism", Journal of Hospitality and Tourism Technology, Vol. 9 No. 3, pp. 238-248.

Rasoolimanesh, S.M., Md Noor, S., Schuberth, F. and Jaafar, M. (2019), "Investigating the effects of tourist engagement on satisfaction and loyalty", The Service Industries Journal, Vol. 39 No. 7-8, pp. 559-574.

Rasoolimanesh, S.M., Khoo-Lattimore, C., Md Noor, S., Jaafar, M. and Konar, R. (2020), "Tourist engagement and loyalty: gender matters?", Current Issues in Tourism, Vol. 24 No. 6, pp. 1-15, available at: https://doi.org/10.1080/13683500.2020.1765321.

Rasoolimanesh, S.M., Taheri, B., Gannon, M., Vafaei-Zadeh, A. and Hanifah, H. (2019), "Does living in the vicinity of heritage tourism sites influence residents' perceptions and attitudes?", Journal of Sustainable Tourism, Vol. 27 No. 9, pp. 1295-1317.

Rather, R.A. and Hollebeek, L. (2019), "Exploring and validating social identification and social exchange-based drivers of hospitality customer loyalty", International Journal of Contemporary Hospitality Management, Vol. 31 No. 3, pp. 1432-1451.

Rather, R.A. and Hollebeek, L. (2021), "Customers' service-related engagement, experience, and behavioral intent: moderating role of age", Journal of Retailing \& Consumer Services, Vol. 60, p. 102453.

Rather, R.A., Hollebeek, L.D. and Islam, J.U. (2019), "Tourism-based customer engagement: the construct, antecedents, and consequences", The Service Industries Journal, Vol. 39 Nos 7/8, pp. 519-540. 
Rather, R.A., Hollebeek, L.D. and Rasoolimanesh, S. (2021), "First-time versus repeat tourism customer engagement, experience, and value co-creation: an empirical investigation", Journal of Travel Research.

Richards, G. (2018), "Cultural tourism: a review of recent research and trends", Journal of Hospitality and Tourism Management, Vol. 36, pp. 12-21.

Ringle, C., Wende, S. and Becker, J. (2015), "SmartPLS3 (Version3.2.3)", SmartPLS.

Russell, J.A. (1980), "A circumplex model of affect", Journal of Personality and Social Psychology, Vol. 39 No. 6, pp. 1161-1178.

Seyfi, S., Hall, C.M. and Rasoolimanesh, S.M. (2020), "Exploring memorable cultural tourism experiences", Journal of Heritage Tourism, Vol. 15 No. 3, pp. 341-357.

Sthapit, E. and Bjork, P. (2019), "Sources of value co-destruction: uber customer perspectives", Tourism Review, Vol. 74 No. 4, pp. 780-794.

Sthapit, E., Björk, P. and Barreto, J.J. (2020), "Negative memorable experience: North American and British airbnb guests' perspectives", Tourism Review, available at: https://doi.org/10.1108/TR-10-2019-0404.

Sthapit, E., Björk, P. and Coudounaris, D.N. (2017), "Emotions elicited by local food consumption, memories, place attachment and behavioural intentions", Anatolia, Vol. 28 No. 3, pp. 363-380.

Sthapit, E., Del Chiappa, G., Coudounaris, D.N. and Bjork, P. (2019), "Tourism experiences, memorability and behavioural intentions: a study of tourists in Sardinia, Italy", Tourism Review, Vol. 75 No. 3 , pp. 533-558.

Timothy, D.J., and Nyaupane, G.P. (Eds) (2009), Cultural Heritage and Tourism in the Developing World: A Regional Perspective, Routledge, Abingdon.

Tsai, C.T. (2016), "Memorable tourist experiences and place attachment when consuming local food", International Journal of Tourism Research, Vol. 18 No. 6, pp. 536-548.

Tsiotsou, R. and Goldsmith, R. (2012), Strategic Marketing in Tourism Services, Emerald, Cheltenham.

Turner, L. and Ash, J. (1975), The Golden Hordes: International Tourism and the Pleasure Periphery, Routledge, London.

Tung, V.W.S. and Ritchie, J.R.B. (2011a), "Exploring the essence of memorable tourist experiences", Annals of Tourism Research, Vol. 38 No. 4, pp. 1367-1386.

Tung, V.W.S. and Ritchie, J.R.B. (2011b), "Investigating the memorable experiences of the senior travel market: an examination of the reminiscence bump", Journal of Travel \& Tourism Marketing, Vol. 28 No. 3 , pp. 331-343

UNESCO (2020), "The historical-cultural axis of fin, sialk, kashan", available at: https://whc.unesco.org/ en/tentativelists/5187 (accessed 1 April 2021)

Van Dijk, P. and Weiler, B. (2009), "An assessment of the outcomes of a Chinese-language interpretive tour experience at a heritage tourism attraction", Tourism Analysis, Vol. 14 No. 1, pp. 49-63.

Woodside, A.G. and Dubelaar, C. (2002), "A general theory of tourism consumption systems: a conceptual framework and an empirical exploration", Journal of Travel Research, Vol. 41 No. 2, pp. 120-132.

Zhang, H., Wu, Y. and Buhalis, D. (2018), "A model of perceived image, memorable tourism experiences and revisit intention”, Journal of Destination Marketing \& Management, Vol. 8, pp. 326-336.

Zhong, Y.Y.S., Busser, J. and Baloglu, S. (2017), "A model of memorable tourism experience: the effects on satisfaction, affective commitment, and storytelling", Tourism Analysis, Vol. 22 No. 2, pp. 201-217.

\section{Further reading}

Chang, J., Okumus, B., Wang, C.H. and Chiu, C.Y. (2020), "Food tourism: cooking holiday experiences in East Asia", Tourism Review, available at: https://doi.org/10.1108/TR-09-2019-0399

Chen, H. and Rahman, I. (2018), "Cultural tourism: an analysis of engagement, cultural contact, memorable tourism experience and destination loyalty", Tourism Management Perspectives, Vol. 26, pp. 153-163.

Rachão, S.A.S., Breda, Z., Fernandes, C. and Joukes, V. (2020), "Food-and-wine experiences towards co-creation in tourism", Tourism Review, available at: https://doi.org/10.1108/TR-01-2019-0026

Timothy, D.J. (2011), Cultural Heritage and Tourism: An Introduction, Channel View Publications, Clevedon. 


\section{Appendix. Adapted items}

1. Hedonism:

- I was thrilled about having a new experience.

- I indulged in the activities.

- I really enjoyed this tourism experience.

- It was exciting.

2. Novelty:

- It was a once-in-a lifetime experience.

- It was unique.

- It was different from previous experiences.

- I experienced something new.

3. Local culture:

- I had a good impression about the local people.

- I closely experienced the local culture.

- Local people in a destination were friendly.

4. Refreshment:

- It was liberating.

- It was refreshing

- I was revitalized.

5. Meaningfulness:

- I did something meaningful.

- I did something important.

- I learned about myself.

6. Involvement:

- I visited a place where I really wanted to go.

- I enjoyed activities, which I really wanted to do.

- I was interested in the main activities of this tourism experience.

7. Knowledge:

- The experience was exploratory.

- I gained a lot of information during the trip.

- I experienced a new culture.

8. Satisfaction:

- Overall, I am satisfied with this travel experience.

- I feel enjoyable about this travel experience.

- I have had a pleasant experience/feeling in this city.

9. Revisit Intention:

- I would revisit this place in the future.

- If given the opportunity, I would return to this place.

- The likelihood of my return to this heritage site for another heritage travel is high.

10. WOM intention:

- I would recommend this place to my friends. 
- When I talk about my visit to the city, I will say good things.

- I would encourage friends and relatives to visit this place.

- I will spread good things about this heritage site in social media.

- I will promote this heritage site.

- I will do some activities to improve the image of the heritage site.

Author affiliations

S. Mostafa Rasoolimanesh is based at Centre for Research and Innovation in Tourism (CRiT), Taylor's University, Subang Jaya, Malaysia.

Siamak Seyfi is based at Geography Research Unit, University of Oulu, Oulu, Finland.

Raouf Ahmad Rather is based at the Central University of Kashmir, Ganderbal, India.

Colin Michael Hall is based at the Department of Management, Marketing and Entrepreneurship, University of Canterbury, Christchurch, New Zealand.

\section{Corresponding author}

Siamak Seyfi can be contacted at: siamak.seyfi@oulu.fi

For instructions on how to order reprints of this article, please visit our website: www.emeraldgrouppublishing.com/licensing/reprints.htm

Or contact us for further details: permissions@emeraldinsight.com 